\title{
A comparative analysis of seismic and tsunami fragility curves for school buildings in Banda Aceh coastal area
}

\author{
Rifqi Irvansyah $^{1 *}$, Ibnu Rusydy ${ }^{12}$, Andrean $V H$ Simanjuntak $^{3}$ \\ ${ }^{1}$ Tsunami and Disaster Mitigation Research Center (TDMRC), Universitas Syiah Kuala (USK), Jl. Hamzah Fanshuri, Darussalam, \\ Banda Aceh, 23111, Indonesia \\ ${ }^{2}$ Department of Geological Engineering, Faculty of Engineering, Universitas Syiah Kuala, Jl. Syeh Abdurrauf No. 7, Banda Aceh, \\ 23111, Indonesia \\ ${ }^{3}$ BMKG, stage of Aceh Besar, Mata Ie, Aceh Besar, 23352, Indonesia
}

\begin{abstract}
The potential for a large disaster in Banda Aceh City requires that the school buildings to be highly resilient to the risks that may arise. One of the efforts to evaluate the performance of the building structure is by developing a fragility curve that shows the probability of damage to school buildings. For seismic susceptibility, the fragility curve is formed using the Incremental Dynamic Analysis method which uses historical earthquake data. As for tsunami susceptibility, the fragility curve is formed by reviewing the inundation heights that have occurred based on the data that have been available. The aim of this study is to elaborate the seismic and tsunami susceptibility of the typical school buildings that located in three coastal districts in Banda Aceh City. The summary results of this study indicate that it is necessary to carry out periodic maintenance of school buildings in the coastal area of Banda Aceh city so that they become strong buildings and are ready to be used if a large-scale disaster occurs.
\end{abstract}

\section{Introduction}

History records that in 2004 a 9.1 magnitude earthquake, followed by a tsunami, devastated the city of Banda Aceh. The impact of the earthquake and tsunami caused damage to the structures and infrastructure, public facilities, and other buildings.

Casualties and damages on educational facilities suffered significant losses. It was noted that 45,000 students and 1,870 teachers died, and 2,065 educational facilities were damaged [1]. Learning from the history of disasters, it is important to ensure the planning, construction, and operation of educational facilities fulfill the earthquake and building standards.

At date, Indonesian building codes regarding earthquake resistant and tsunami loads for building are following the SNI 1726-2019 [2] and SNI 1727-2020 [3]. Since, the feasibility study of school buildings against earthquake and tsunami hazards is crucial, therefore, it is important to ensure that the school building structures are planned to be safe against earthquakes and tsunamis, specifically in coastal areas.

The earthquake and tsunami risk of school buildings in Banda Aceh had been assessed and reported by Gentile [4]. According to Gentile et al. [4], the seismic fragility of school buildings post-2012 is decreased compared to the pre-2012 structures. The relative seismic risk of the considered buildings is particularly similar, while the relative tsunami risk shows a strong dependence with the distance from the coast.
The purpose of this study is to develop the analytical fragility curve for the typical school's building in Banda Aceh. The fragility curve will show the probability of damage of the building structure in various damage level, namely slight damage, moderate damage, extensive damage, and complete damage. By referring to the fragility curve, an assessment on the vulnerability of buildings due to earthquakes and tsunamis can be predicted. The seismic fragility curve is formed using the Incremental Dynamic Analysis (IDA) method [5] and producing an IDA curve. This IDA Curve will be analyzed further to develop a seismic fragility curve. While the tsunami fragility curve is formed by calculating the cumulative probability of a measure of the tsunami intensity, which is the height of the tsunami inundation [6] and producing capacity curve. The capacity curve will be analyzed further to develop a tsunami fragility curve.

In this study an analytical fragility curve shows the probability of damage to school buildings in 3 coastal districts of Banda Aceh City based on the analysis of earthquake and tsunami loading. With the probability of damage to the building, the results can mitigate disasters in the future. The potential liquefaction impact on the buildings will also be assessed based on the calculated liquefaction map of Banda Aceh.

\footnotetext{
*Corresponding author: rifqirvansyah@gmail.com
} 


\section{Methodology}

\subsection{Research object}

The object of this study is school buildings located in 3 coastal districts in Banda Aceh City. Field surveys were carried out on 51 buildings from 34 schools. The location of the schools is plotted in Fig 1.

According to the school building data obtained from the field surveys, 3 schools building was chosen representing the 3 coastal districts. These buildings were selected since it could represent the most dominant building form, the most dominant number of floors, the distance to the closest fault, and the closest distance to the beach. The three buildings are :

1. Schools in Syiah Kuala District are represented by SDN 15 Banda Aceh with the following data:

- Construction type: Reinforced Concrete (RC)

- Number of Floors: 2 stories

- Stories height: $4 \mathrm{~m}$ ( $1^{\text {st }}$ floor $), 3.5 \mathrm{~m}$ ( $2^{\text {nd }}$ floor $)$

- Structural dimensions:

Columns: rectangular column with $300 \times 400 \mathrm{~mm}$ Beams: rectangular beams with $300 \times 400 \mathrm{~mm}$ and $450 \times 550 \mathrm{~mm}$.

2. Schools in Kutaraja District are represented by SDN 70 Banda Aceh with the following data:

- Construction type: Reinforced Concrete (RC)

- Number of Floors: 2 stories

- Stories height: $3,5 \mathrm{~m}$

- Structural dimensions:

Columns: rectangular column with 300x300 mm Beams: rectangular beams with 250 x $400 \mathrm{~mm}$ and $300 \times 500 \mathrm{~mm}$.

3. Schools in Meuraxa District are represented by SDN 7 Banda Aceh with the following data:

- Construction type: Reinforced Concrete (RC)

- Number of Floors: 2 stories

- Stories height: $3 \mathrm{~m}$

- Structural dimensions:

Columns: rectangular column with 300 x $300 \mathrm{~mm}$ Beams: rectangular beams with $300 \times 400 \mathrm{~mm}$ and $450 \times 600 \mathrm{~mm}$.

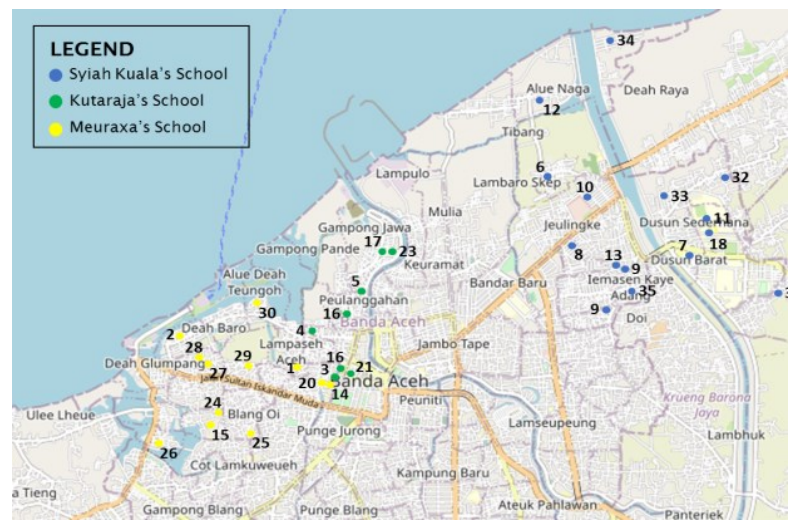

Fig 1. Map of the distribution of schools that have been surveyed

\subsection{Modeling structure}

The selected buildings were modelled by using the structural analysis software of SAP2000. Then, finite element (FE) analysis was performed to analysed each model against the earthquake and the tsunami loading. Fig 2 to Fig 4 shows the school building and the FE model of each representative building, respectively.

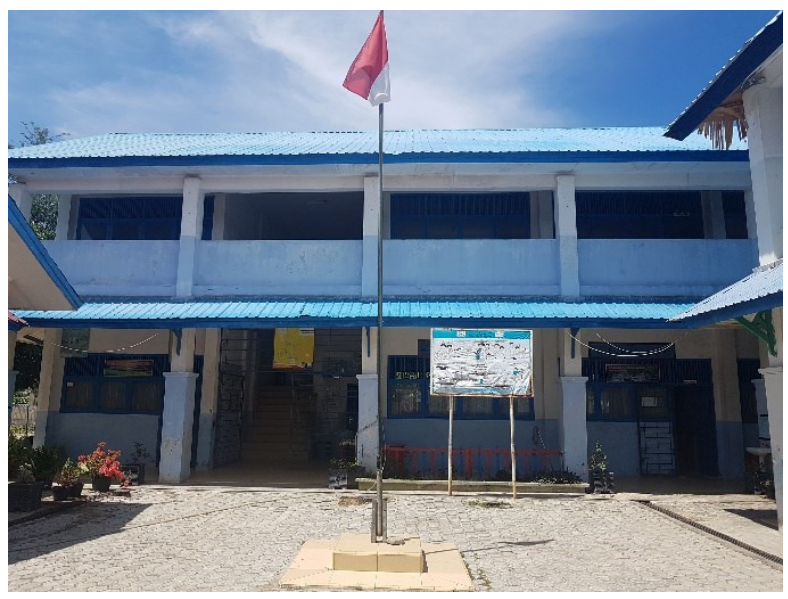

Fig 2 (a). Syiah Kuala's school building

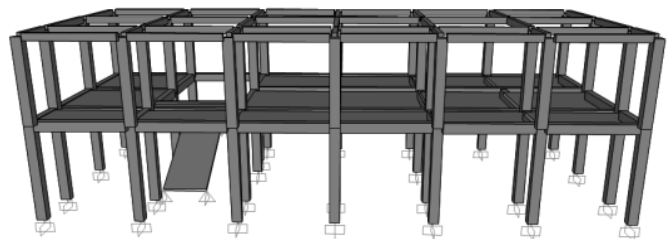

Fig 2 (b). Syiah Kuala's school 3D modelling

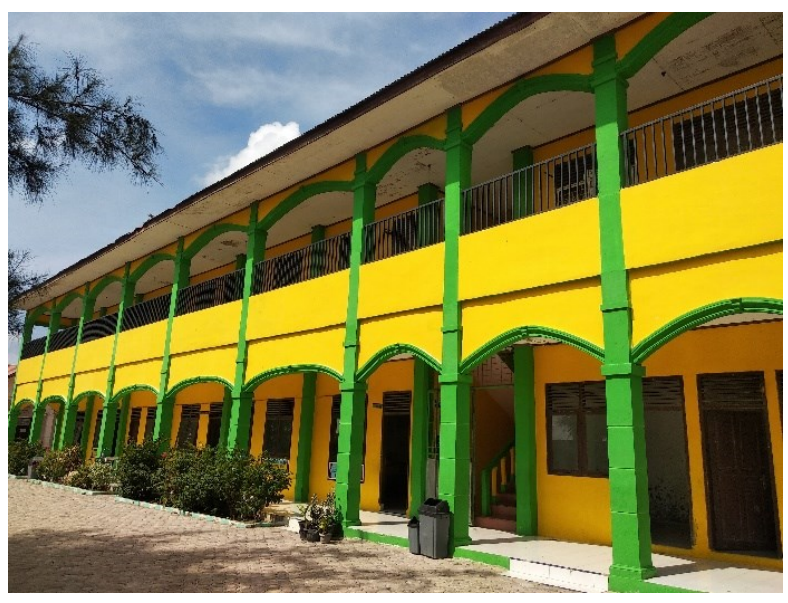

Fig 3 (a). Kutaraja's school building

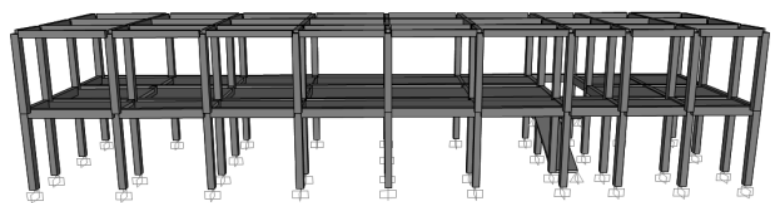

Fig 3 (b). Kutaraja's school 3D modelling 


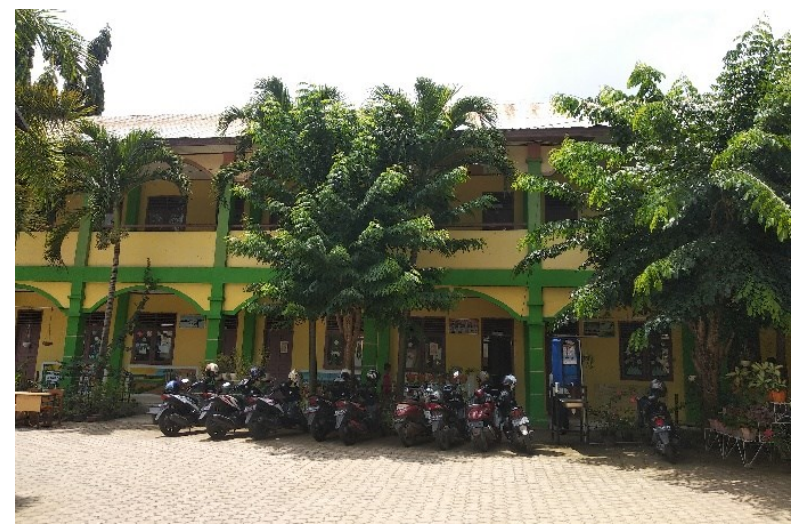

Fig 4 (a). Meuraxa's school building

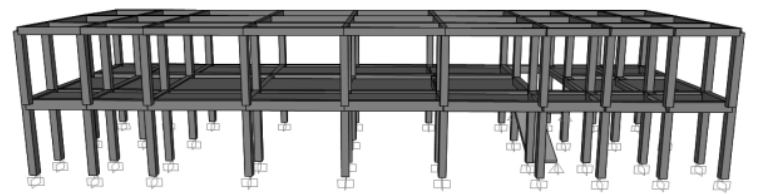

Fig 4 (b). Meuraxa's school 3D modelling

\subsection{Response spectrum}

The earthquake load indicated in the SNI earthquake is in the form of a spectrum response following the 2017 Earthquake Source and Hazard Map [7]. The rules for determining the spectrum response refer to the SNI 1726-2019 regulations. Based on the calculation of SNI 1726-2019, the spectrum response in the three review districts is as follows:

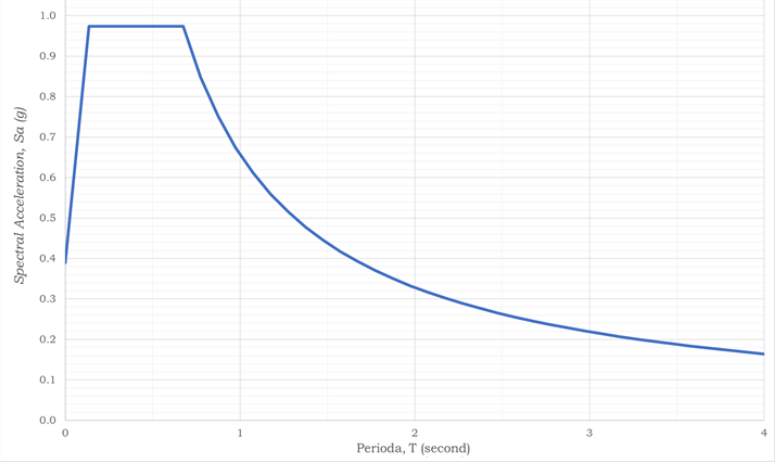

Fig 5. Spectrum response of Syiah Kuala's school

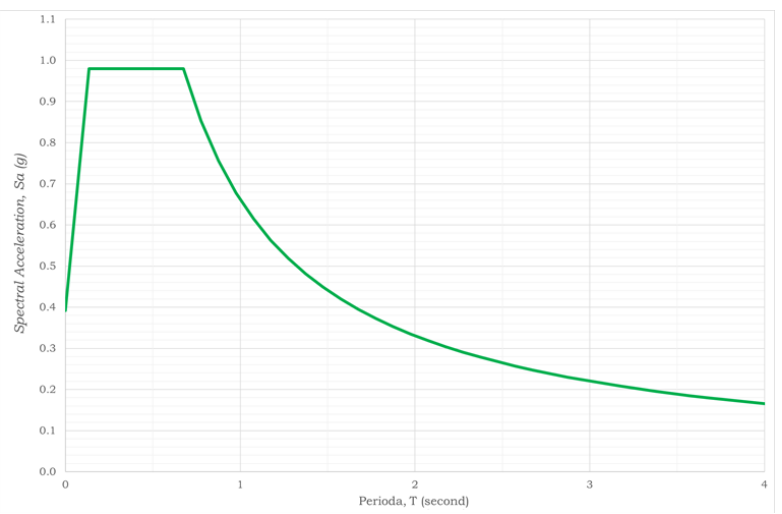

Fig 6. Spectrum response of Kutaraja's school

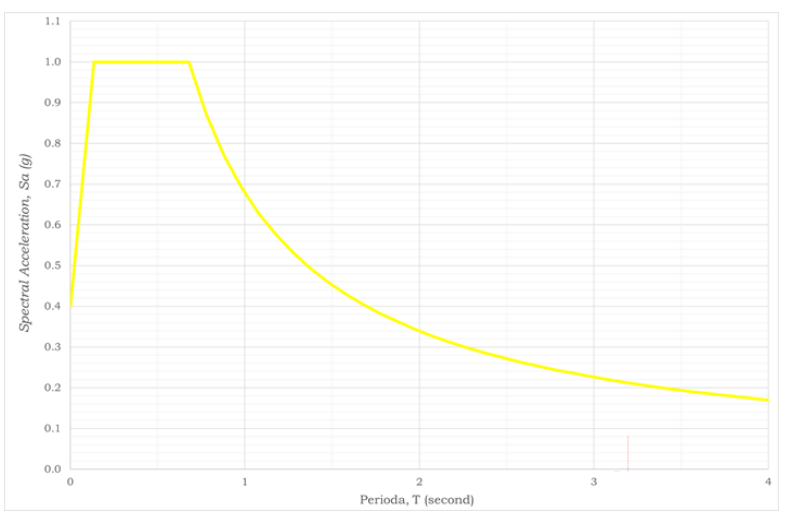

Fig 7. Spectrum response of Meuraxa's school

\subsection{Ground motion records}

Earthquake data taken are earthquakes that have occurred in Aceh and caused severe damage to structures. This study used 12 ground motion records which can be seen in Table 1 .

Table 1. Ground motion records used

\begin{tabular}{|l|c|}
\hline Ground Motion Record & Mw \\
\hline Andaman-East 2004 & 9,1 \\
\hline Andaman-North 2004 & 9,1 \\
\hline Simeulu 1-East 2012 & 8,5 \\
\hline Simeulu 1-North 2012 & 8,5 \\
\hline Simeulu 2-East 2012 & 8,1 \\
\hline Simeulu 2-North 2012 & 8,1 \\
\hline Bener Meriah-East 2013 & 6,1 \\
\hline Bener Meriah-North 2013 & 6,1 \\
\hline Pidie Jaya-East 2016 & 6,5 \\
\hline Pidie Jaya-North 2016 & 6,5 \\
\hline Banda Aceh-East 2020 & 5,5 \\
\hline Banda Aceh-North 2020 & 5,5 \\
\hline Source : BMKG database [8]
\end{tabular}

The ground motion data in a waveform in ASCII format was converted into an accelerogram using the DADiSP/SE 6.7 application. Then the accelerogram is converted into a response spectrum using seismosignal software. Furthermore, the response spectrum of various earthquakes is matched to the response spectrum of the target using seismomatch software by adjusting the scale factor to obtain a spectrum that matches the design response spectrum. The scale factor calculation uses the spectral acceleration value of the ground motion records response with the spectral acceleration value of the target response spectrum.

A frequency content modification method called spectral matching is used to adjust ground motion records to the target response spectrum. To adjust the ground motion record with the target response spectra using a scale factor. The calculation of the scale factor (SF) is based on the following Kalkan and Chopra formula [9]: 


$$
S F=\frac{\sum_{i=1}^{n} \overline{\mathrm{A}} \mathrm{Ai}}{\sum_{i=1}^{n} \mathrm{Ai} \mathrm{Ai}}
$$

with;

$\mathrm{SF}=$ scale factor, $\overline{\mathrm{A}}=$ Spectral acceleration target, $\mathrm{Ai}=$ Spectral acceleration scaled

The accelerogram that has been scaled is inputted into SAP2000 as a load with a scale factor $=\mathrm{g} \mathrm{I} / \mathrm{R}$, where $\mathrm{g}$ $=$ acceleration due to gravity $\left(9.81 \mathrm{~m} / \mathrm{s}^{2}\right)$, I is the main earthquake factor, which is 1.5 as a building risk categorized as number IV (important building for disaster mitigation), and $\mathrm{R}$ is a reduction coefficient factor of 8 .

\subsection{Tsunami loading}

Tsunami loading is determined based on regulations from SNI 1727-2020. The tsunami forces reviewed are hydrostatic, hydrodynamic, and floating debris collision, which can be seen in table 2 . These forces are inputted to the building according to the direction of the tsunami and the height of the inundation that occurs.

Tabel 2. The formula of the tsunami force based on SNI 1727-2020

\begin{tabular}{|l|l|c|}
\hline Type of Forces & Tsunami Consideration & \multicolumn{1}{c|}{ Formula } \\
\hline Hydrostatic & $\begin{array}{l}\text { Hydrostatic forces occur when slowly moving water hits a } \\
\text { member of the structure. }\end{array}$ & $\mathrm{F}_{\mathrm{h}}=\frac{1}{2} \gamma_{\mathrm{s}} \mathrm{bh}^{2}{ }_{\max } \quad(2)$ \\
\hline Hydrodynamic & $\begin{array}{l}\text { Hydrodynamic forces are used when water flows around the } \\
\text { building structure }\end{array}$ & $\mathrm{F}_{\mathrm{d}}=\frac{1}{2} \rho_{\mathrm{s}} \mathrm{I}_{\mathrm{TSU}} \mathrm{C}_{\mathrm{d}} \mathrm{b}\left(\mathrm{h}_{\mathrm{e}} u^{2}\right) \quad(3)$ \\
\hline $\begin{array}{l}\text { Floating debris } \\
\text { impact }\end{array}$ & $\begin{array}{l}\text { Impact forces originating from debris drift can cause damage } \\
\text { to buildings. }\end{array}$ & $\mathrm{F}_{\mathrm{i}}=1,47 \mathrm{C}_{0} \mathrm{I}_{\mathrm{tsu}}[\mathrm{KN}] \quad(4)$ \\
\hline
\end{tabular}

with;

$\gamma_{\mathrm{s}}=$ weight density of hydrostatic fluid $\left(\mathrm{kg} / \mathrm{m}^{3}\right)$

$\mathrm{b} \quad=$ width of the column under force $(\mathrm{m})$

$\mathrm{h}_{\max }=$ maximum inundation depth $(\mathrm{m})$

$\rho_{\mathrm{s}} \quad=$ mass density of hydrodynamic fluid $\left(\mathrm{kg} / \mathrm{m}^{3}\right)$

$\mathrm{I}_{\mathrm{tsu}}=$ priority factor for tsunami force

$\mathrm{C}_{\mathrm{d}}=$ drag coefficient based on quasi-steady force

$\mathrm{h}_{\mathrm{e}}$ = inundation height of individual elements (m)

$\mathrm{u}=$ tsunami flow velocity $(\mathrm{m} / \mathrm{det})$

$\mathrm{C}_{\mathrm{o}}=$ coefficient of orientation (of debris)

The calculation of the tsunami load is carried out by simulating buildings with a tsunami flow height that has occurred, such as the 2004 tsunami. The data was obtained based on previous research, as Iemura [10] and Tursina [11]. Iemura's research [10] shows the distribution of the Tsunami Pole points, which shows the height of the tsunami inundation. Meanwhile, Tursina's research [11] is based on the 2004 tsunami flow depth simulation in Banda Aceh using NOAA survey data and the Tsunami Pole. The value of the inundation depth that occurs at the object point can be seen based on Tursina [11], but the data is in the form of a range of values so that the value to be used is difficult to determine. For this reason, a comparison is made with Iemura [10] research, which shows the value of inundation depth based on the nearest tsunami pole. The value of the tsunami inundation that occurred at the coordinates of the building under study can be seen in table 3 .

Tabel 3. Data of tsunami inundation 2004

\begin{tabular}{|c|c|c|}
\hline \multirow{2}{*}{$\begin{array}{c}\text { School } \\
\text { Building }\end{array}$} & \multicolumn{2}{|c|}{ Tsunami Inundation based on: } \\
\cline { 2 - 3 } & $\begin{array}{c}\text { The Nearest } \\
\text { Tsunami Poles - } \\
\text { Iemura [10] }\end{array}$ & $\begin{array}{c}\text { Tsunami flow } \\
\text { depth simulation - } \\
\text { Tursina [1] }\end{array}$ \\
\hline Syiah Kuala & $3.8 \mathrm{~m}$ & $2-4 \mathrm{~m}$ \\
\hline
\end{tabular}

\begin{tabular}{|l|l|l|}
\hline Kutaraja & $7 \mathrm{~m}$ & $4-6 \mathrm{~m}$ \\
\hline Meuraxa & $7 \mathrm{~m}$ & $4-6 \mathrm{~m}$ \\
\hline
\end{tabular}

The height of the tsunami inundation is taken in stages starting from $1 \mathrm{~m}, 2 \mathrm{~m}, 3 \mathrm{~m}$, and so on until the highest tsunami height occurs. The result of this height difference shows the drift ratio at each level. The tsunami loading will be carried out in combination with the tsunami loading based on SNI 1727-2020 using the equation:

$$
\begin{aligned}
& 1,2 \mathrm{D}+\mathrm{F}_{\mathrm{TSU}}+0,5 \mathrm{~L}+0,2 \mathrm{~S} \\
& 0,9 \mathrm{D}+\mathrm{F}_{\mathrm{TSU}}
\end{aligned}
$$

with;

$$
\begin{aligned}
& \mathrm{D}=\text { Dead load } \\
& \mathrm{L}=\text { Live load } \\
& \mathrm{S}=\text { Snow load } \\
& \mathrm{F}_{\mathrm{TSU}}=\text { Tsunami Force }
\end{aligned}
$$

In terms of the combination of tsunami loading, it does not take into account the seismic damage at the initial state of capacity reduction. The Seismic and tsunami analysis are two different independent analysis.

\subsection{Incremental dynamic analysis}

According to Tiwari and Kasnale [12], incremental dynamic analysis (IDA) is an analysis to study the whole earthquake with different intensities, which is applied to the building structure model until it collapses. IDA is done by performing a non-linear time history analysis. In a non-linear time history analysis, the structure is assigned one or more accelerograms multiplied by a scale factor, which are performed at various levels of earthquake intensity that are expected to occur. The level of additional earthquake intensity is increased until 
the structure experiences an elastic phase to a plastic phase (inelastic) until it finally reaches global dynamic instability or the structure collapses. The IDA method will be used in a combination of earthquake loading based on SNI 1726-2019 using the equation:

$$
\begin{aligned}
& 1,2 \mathrm{D}+\mathrm{Ev}+\mathrm{Emh}+\mathrm{L} \\
& 0,9 \mathrm{D}-\mathrm{Ev}+\mathrm{Emh}
\end{aligned}
$$

with;

$\mathrm{Ev}=$ Effect of vertical seismic force

Emh $=$ Effect of horizontal seismic force

After the structural modeling is completed, the next step is to input the earthquake history data used. Then run a dynamic analysis of time history gradually with an increasing earthquake intensity scale. The analysis was carried out using the addition of a scale factor of $0.5 ; 1$ and 2. These additions are used to determine the limits of repeated load increases. The results of the analysis are displacements in the $\mathrm{x}$ and $\mathrm{y}$ directions. This displacement value is used to determine the value of the drift ratio, which is useful in making the IDA curve.

\subsection{Seismic fragility curve}

Based on the structural analysis results using the IDA method, IDA curves with various variations are obtained according to the number of earthquake records used as earthquake loads. The IDA curve can be analyzed further probabilistically by using the fragility function and expressed in a fragility curve. In this study, the value of limit states follows the research of Kim and Shinozuka, which is summarized in Pitiliakis [13].

Tabel 4. Limit states IDA method

\begin{tabular}{|l|c|}
\hline Damage states & Drift Ratio \\
\hline Slight & $0.7 \%$ \\
\hline Moderate & $1.5 \%$ \\
\hline Extensive & $2.5 \%$ \\
\hline Complete & $5.0 \%$ \\
\hline
\end{tabular}

The fragility curve shows the probability of damage to a structure when it receives an earthquake load with a certain intensity at its service limit. Based on the analytical method, the function is derived by Sadradin [14] through the log-normal distribution approach as follows:

$P=\phi\left(\frac{\ln (\mathrm{X})-\lambda)}{\beta_{\mathrm{RU}}}\right)$

with;

$\mathrm{P}=$ Probability of structural damage,

$\Phi=$ Standard normal function of cumulative distribution,

$\beta_{\mathrm{RU}}=$ The total uncertainty of the structure,

$\mathrm{x}=$ Ground motion parameter, PGA $(\mathrm{g})$,

$\lambda=$ mean of $\ln (\mathrm{x})$.

\subsection{Tsunami fragility curve}

To construct a tsunami fragility curve, data on tsunami inundations that have occurred is needed. The data was obtained based on previous research, as Iemura [10] and Tursina [11]. The tsunami fragility curve depicts the probability of a specified level of damage in a tsunami event with a certain tsunami inundation intensity. In this study, the fragility curve was calculated using the cumulative distribution of the damage index and the lognormal function. The level of damage reviewed is seen based on the value of the drift ratio that occurs; this provision is determined by what is summarized by Medina [15], whose limit states can be seen in Table 5.

Table 5. Damage states limits of tsunami fragility function

\begin{tabular}{|l|c|}
\hline \multicolumn{1}{|c|}{ Damage States } & $\begin{array}{c}\text { Drift Damage Index } \\
\text { HAZUS }-\mathbf{1}-3 \text { stories }\end{array}$ \\
\hline Slight & $<0.20 \%$ \\
\hline Moderate & $0.20 \%-0.50 \%$ \\
\hline Extensive & $0.50 \%-1.20 \%$ \\
\hline Complete & $1.20 \%-2.80 \%$ \\
\hline
\end{tabular}

The results of non-linear numerical analysis of the tsunami inundation depth and the drift ratio obtained are used to obtain a tsunami fragility curve expressed as a two-parameter log-normal distribution function. The tsunami fragility curve equation used is based on Karafagka's research [6] which provides an assessment of the cumulative probability of exceeding the level of damage conditioned on the measure of tsunami intensity.

$\mathrm{P}_{(\mathrm{DSi} \mid \mathrm{IM})}=\Phi\left(\frac{\ln (I M)-\ln \left(\overline{I M_{\mathrm{t}}}\right)}{\beta}\right)$

Where $\Phi$ is a standard normal cumulative distribution function, IM is a measure of tsunami intensity expressed in inundation depth (in units of m), IMi is the median value (in units of $\mathrm{m}$ ) for each level of damage. It is the uncertainty calculated via the log standard deviation parameter in each damage level. The uncertainty value can be calculated using the following equation:

$\beta=\sqrt{\beta_{c}^{2}+\beta_{D}^{2}}$

Where $\beta_{\mathrm{C}}$ is the structural capacity uncertainty taken as 0.15 (based on the HAZUS MH Technical Manual) [16] and $\mathrm{D}$ is the structural review uncertainty taken into account by calculating the logarithmic dispersion at each level of damage. The results of the calculation of the standard deviation of the total uncertainty in each damage condition.

\section{Result and discussion}

\subsection{Results of IDA curve analysis}

In making the IDA curve, an Intensity measure in Peak Ground Acceleration (PGA) is needed for the $\mathrm{x}$-axis. Meanwhile, the damage measure used is the drift ratio for the $y$-axis. The analysis was stopped when the drift 
ratio was more than $7-8 \%$ because it had crossed the largest limit state value. The results of the IDA curve analysis for earthquakes in the $\mathrm{x}$ and $\mathrm{y}$ directions can be seen in Fig 8.
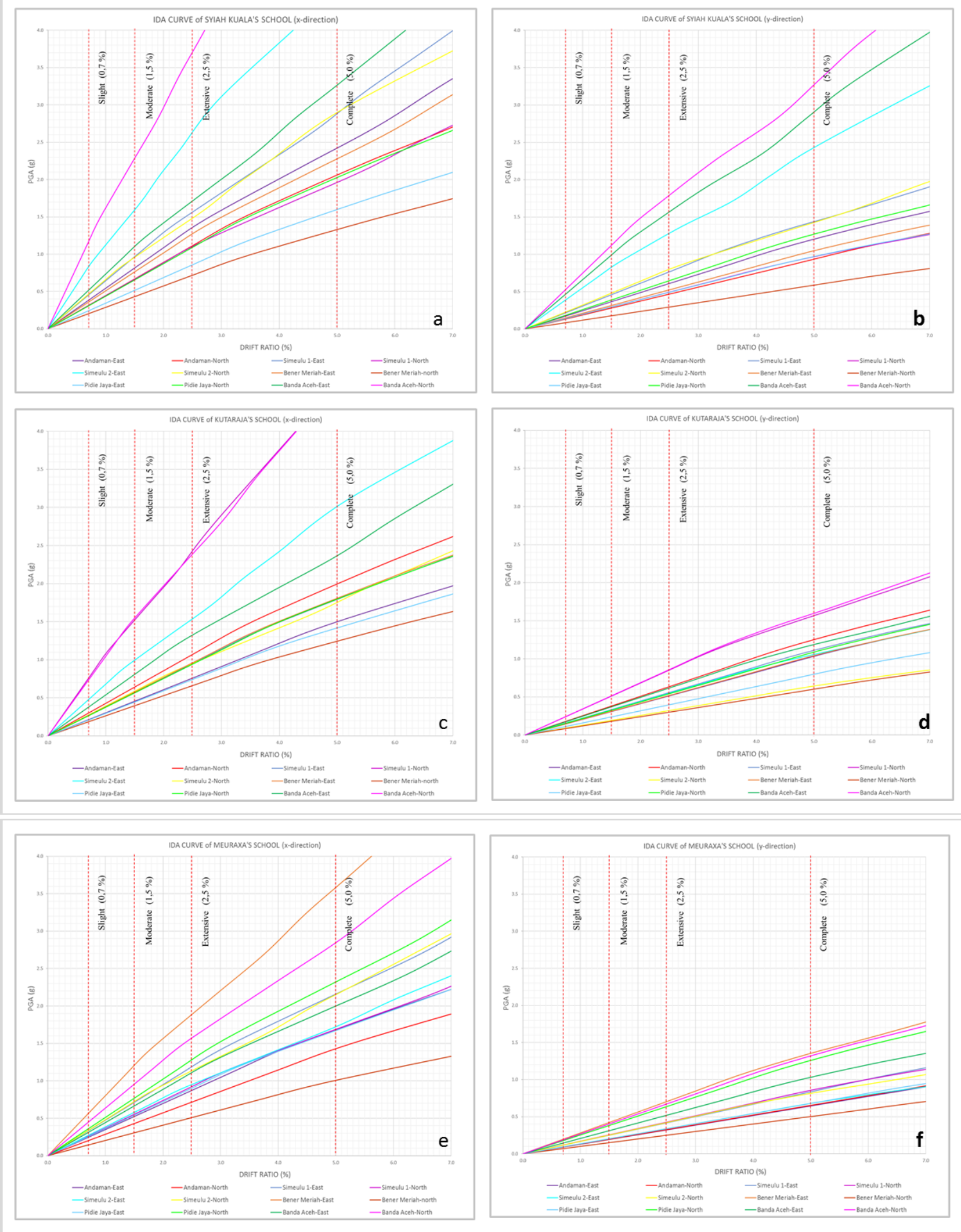

Fig 8. IDA curve of 3 school buildings with two direction 


\subsection{Result of tsunami capacity curve analysis}

The drift ratio resulting from differences in the modeled tsunami inundation is used to determine the structure's capacity limit. This value is adjusted to the inundation height to form a capacity curve. This curve is needed to form a tsunami fragility curve which requires a limit value of the drift ratio that occurs with the depth of the modeled tsunami inundation. The value of inundation depth at each damage limit for each height can be seen in Fig 9.

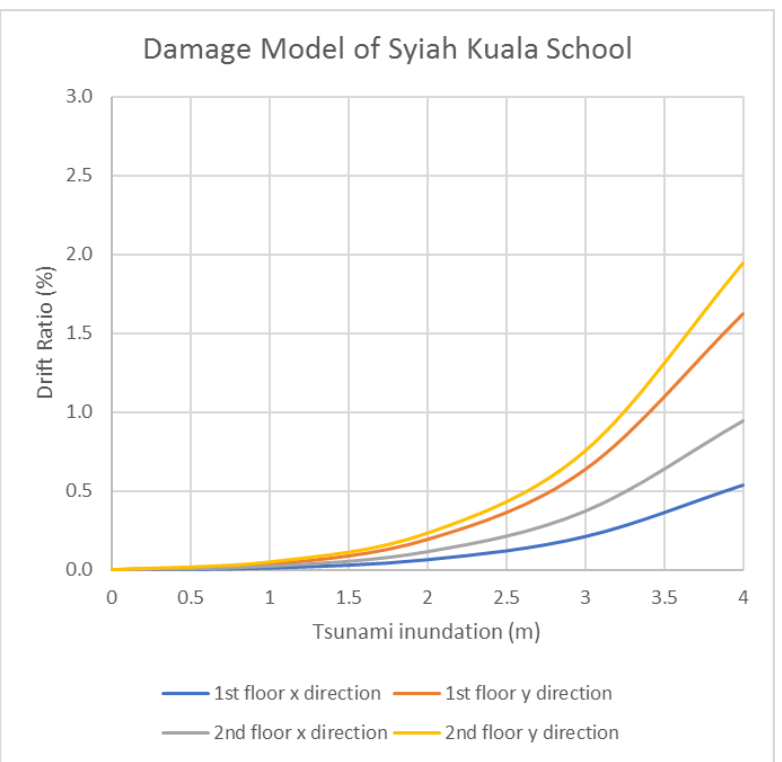

Fig 9 (a). Tsunami damage state of Syiah Kuala's school

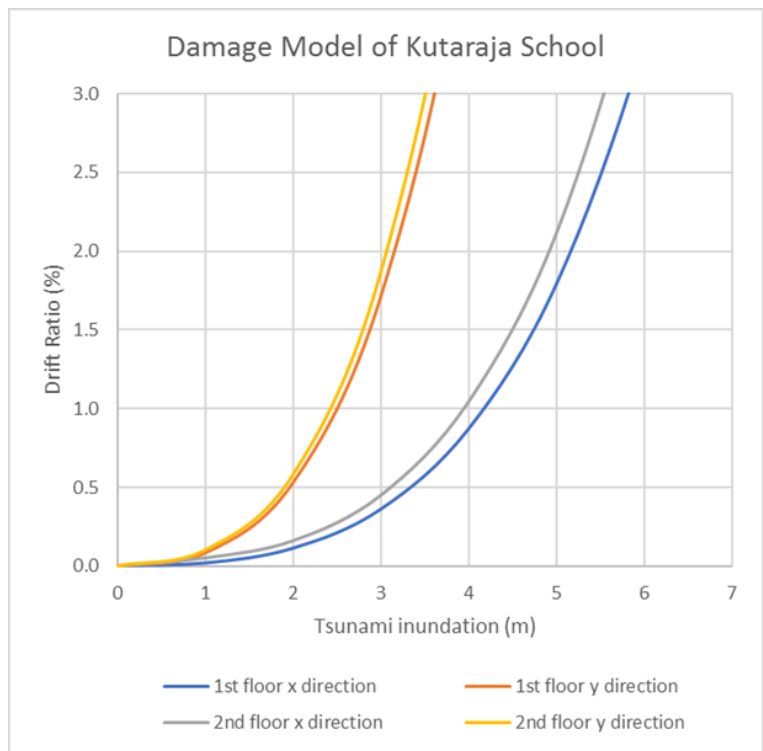

Fig 9 (b). Tsunami damage state of Kutaraja's school

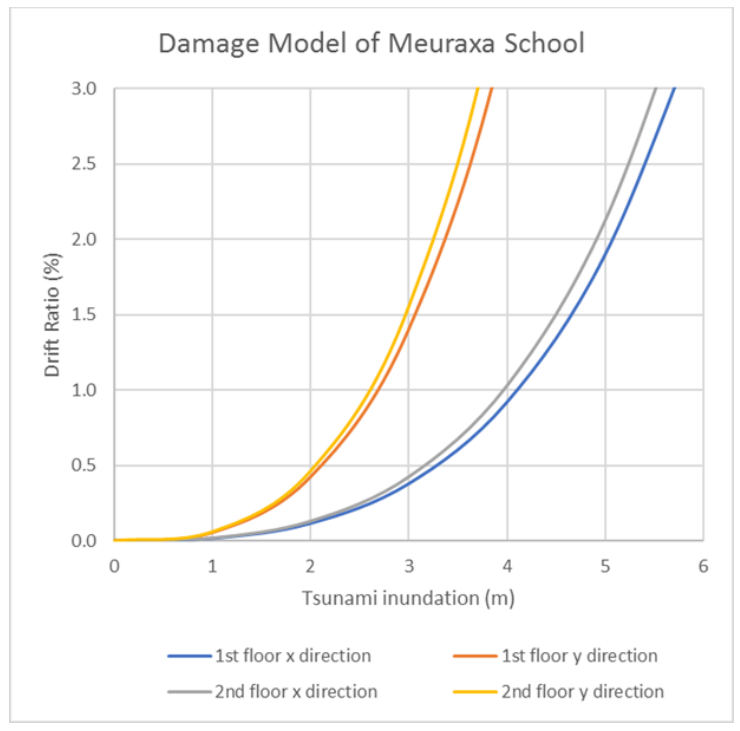

Fig 9 (c). Tsunami damage state of Meuraxa's school

\subsection{Results of seismic fragility curve analysis}

The variables needed to form the seismic fragility curve are the ground motion parameter (PGA), the average of the ground motion parameters according to the limit state, and the total uncertainty. Based on these results, the complete fragility probability value is obtained at various limit states. The fragility probability value is plotted on the y-axis (ordinate) and the ground motion parameter on the $\mathrm{x}$-axis (abscissa). With this curve, the evaluation of the probability of the building structure being damaged due to variations in the intensity of the earthquake load during its service life can be carried out quantitatively and rationally. The results of the fragility curve in the $\mathrm{x}$ and $\mathrm{y}$ directions can be seen in Fig 10 . 

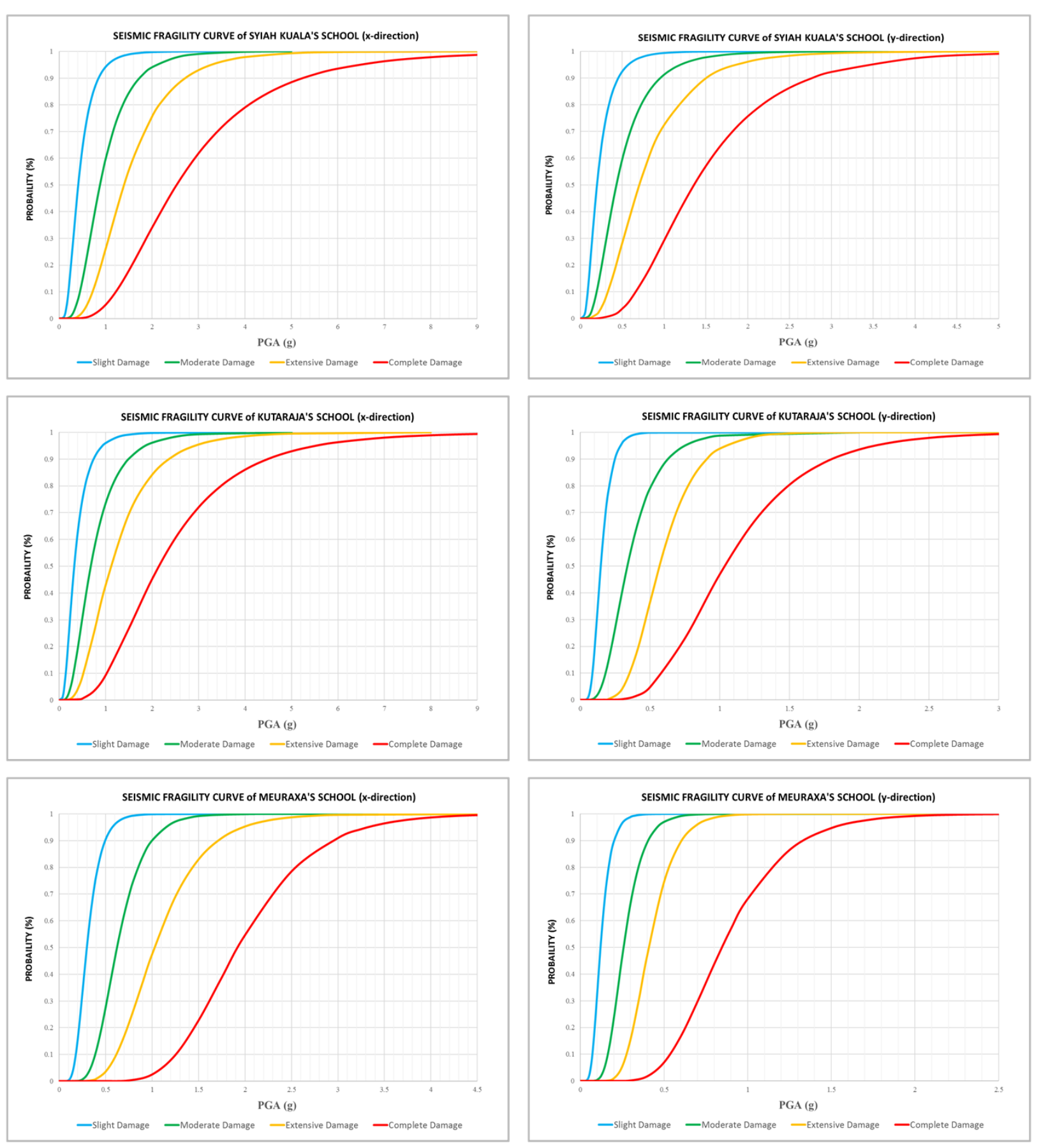

Fig 10. Seismic fragility curve

With the fragility curve, the evaluation of postearthquake structural failure is easier to predict. The trick is to assume the magnitude of the earthquake that will occur in the future. For example, it is assumed that in the future, there will be an earthquake with a PGA value of $0.75 \mathrm{~g}$, then the possibility of damage to the school building structure can be seen in Table 6 as follows:
Table 6. Probability of damage due to an earthquake with PGA prediction $0.75 \mathrm{~g}$

\begin{tabular}{|c|c|c|c|c|c|}
\hline \multirow{2}{*}{$\begin{array}{c}\text { Building } \\
\text { School with } \\
\text { PGA value } \\
\text { 0.75 g }\end{array}$} & \multicolumn{4}{|c|}{ Probability of Damage (\%) } \\
\cline { 2 - 6 } & Slight & Moderate & Extensive & Complete \\
\hline \multirow{2}{*}{$\begin{array}{c}\text { Syiah } \\
\text { Kuala }\end{array}$} & $\mathrm{x}$ & 86 & 38 & 11 & 2 \\
\cline { 2 - 6 } & $\mathrm{y}$ & 98 & 83 & 55 & 14 \\
\hline \multirow{2}{*}{ Kutaraja } & $\mathrm{x}$ & 91 & 55 & 24 & 4 \\
\cline { 2 - 6 } & $\mathrm{y}$ & 100 & 95 & 79 & 24 \\
\hline \multirow{2}{*}{ Meuraxa } & $\mathrm{x}$ & 99 & 70 & 21 & 1 \\
\cline { 2 - 6 } & $\mathrm{y}$ & 100 & 100 & 97 & 35 \\
\hline
\end{tabular}




\subsection{Results of tsunami fragility curve analysis}

The results of displacement and drift ratio show that for each modeled tsunami height, it is seen that the building structure deforms and responds differently. But in general, it has the same tendency; the displacement in the $\mathrm{y}$-direction is bigger than in the $\mathrm{x}$-direction. However, it depends on the condition of the direction of the tsunami and the height of the inundation that occurs. On the tsunami fragility curve, the probability value is plotted on the $y$-axis (ordinate) and the inundation depth on the $x$ axis (abscissa). The results of the tsunami fragility curve formed at various damage limits can be seen in Fig 11 .
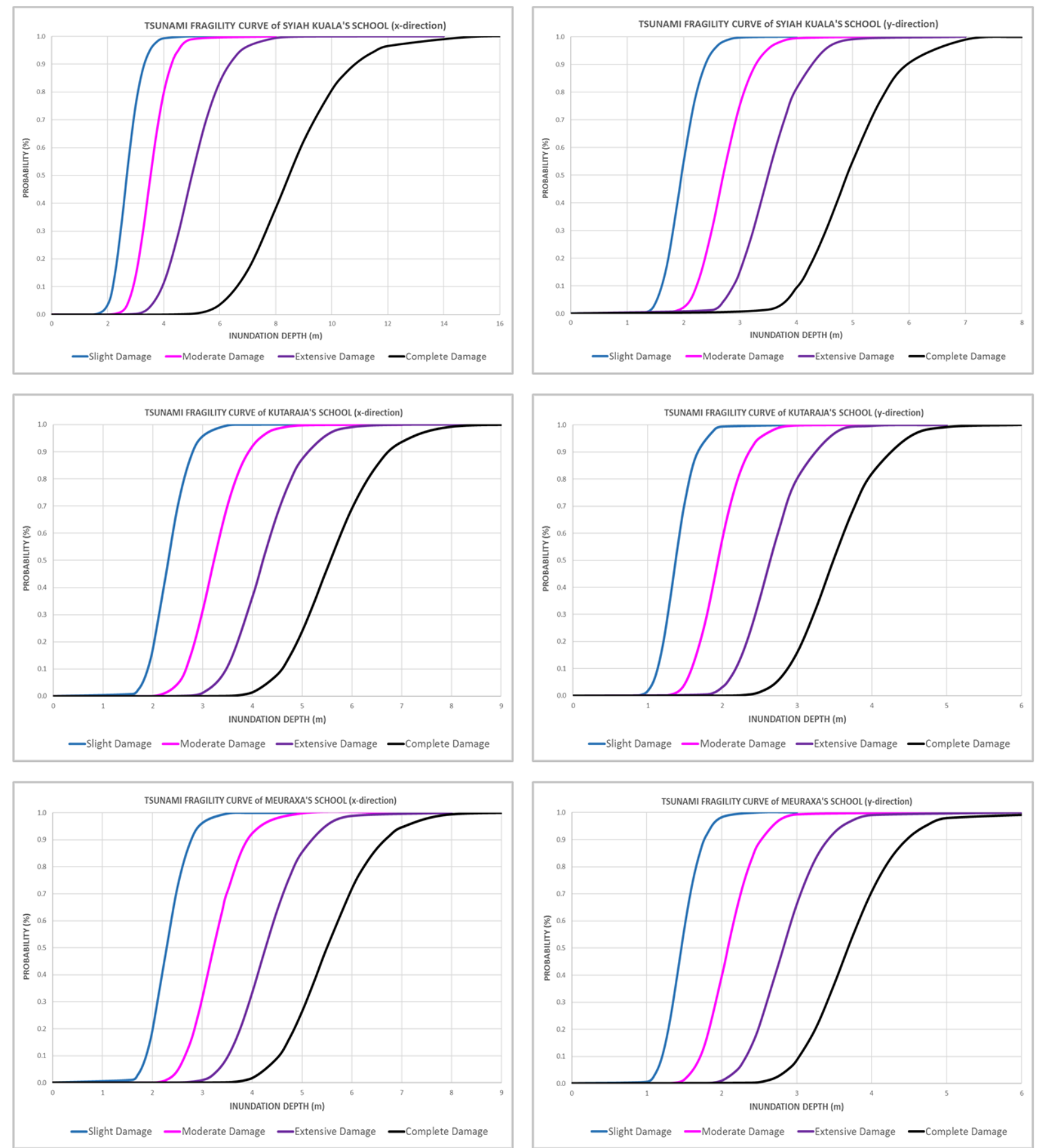

Fig 11. Tsunami fragility curve

The tsunami fragility curve can also predict the damage that occurs by assuming the height of the tsunami inundation that will occur in the future. For example, it is assumed that in the future, there will be a tsunami with an inundation depth of $3 \mathrm{~m}$, then the possibility of

damage to the school building structure can be seen in Table 7 as follows: 
Table 7. Probability of damage due to a tsunami with a predicted inundation depth of $3 \mathrm{~m}$

\begin{tabular}{|c|c|c|c|c|c|}
\hline \multicolumn{2}{|c|}{$\begin{array}{c}\text { Building } \\
\text { School with } \\
\text { inundation } \\
\text { depth 3 m }\end{array}$} & \multicolumn{4}{|c|}{ Probability of Damage (\%) } \\
\cline { 2 - 6 } & Slight & Moderate & Extensive & Complete \\
\hline \multirow{2}{*}{$\begin{array}{c}\text { Syiah } \\
\text { Kuala }\end{array}$} & $\mathrm{x}$ & 72 & 18 & 1 & 0 \\
\cline { 2 - 6 } & $\mathrm{y}$ & 100 & 78 & 16 & 2 \\
\hline \multirow{2}{*}{ Kutaraja } & $\mathrm{x}$ & 95 & 31 & 2 & 0 \\
\cline { 2 - 6 } & $\mathrm{y}$ & 100 & 100 & 80 & 15 \\
\hline \multirow{2}{*}{ Meuraxa } & $\mathrm{x}$ & 96 & 32 & 2 & 0 \\
\cline { 2 - 6 } & $\mathrm{y}$ & 100 & 100 & 68 & 9 \\
\hline
\end{tabular}

\subsection{The result of liquefaction vulnerability}

In addition to vulnerability due to the earthquake and tsunami, it is also necessary to review the vulnerability to potential liquefaction. The potential for liquefaction in Banda Aceh City can be seen in Rusydy's research [17] which describes a map of the potential for liquefaction based on a groundwater level map and a map of the vulnerability of the soil to liquefaction. Liquefaction is assumed to cause additional damage to buildings in the light, medium, high, and very high vulnerability zones. The distribution of school buildings on the liquefaction vulnerability map can be seen in Fig 12.

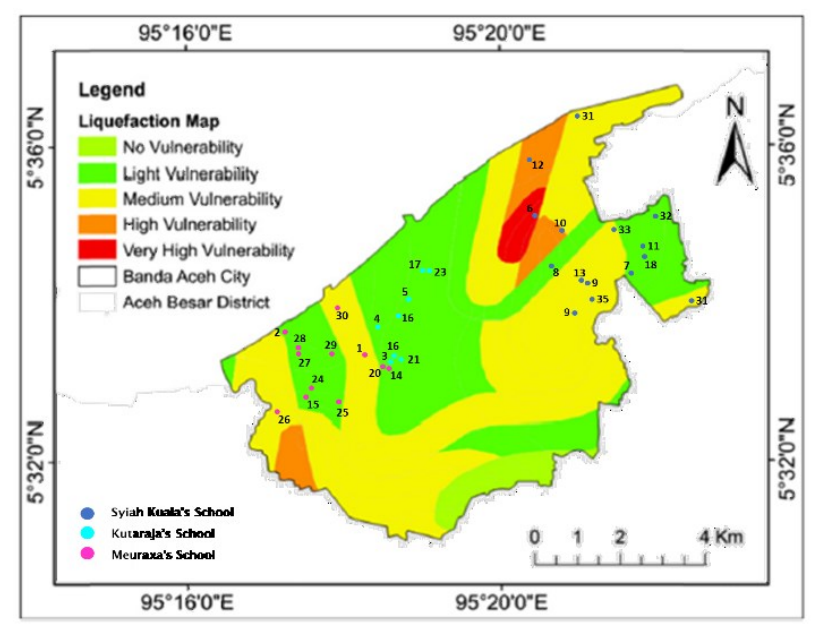

Fig 12. The distribution of school buildings on the liquefaction vulnerability map [17].

Based on the map above, it can be seen that generally, school buildings in the coastal area of Banda Aceh City have a light vulnerability, which means they are still in the safe stage. However, this potential vulnerability cannot be ignored because several schools are included in the medium vulnerability area, so further action is needed for disaster mitigation efforts.

\section{Conclusion}

The seismic fragility curve analysis results show that the building structure is more susceptible to the y-direction than the $\mathrm{x}$-direction. The vulnerability values studied each has a $100 \%$ probability of damage, as shown in Table 8. For vulnerability due to tsunami, the building structure has a $100 \%$ probability of damage, as shown in Table 9.

Table 8. The result of seismic fragility curve

\begin{tabular}{|c|c|c|c|c|c|}
\hline \multirow{2}{*}{$\begin{array}{c}\text { Building } \\
\text { School }\end{array}$} & \multicolumn{4}{|c|}{ Peak Ground Acceleration (g) } \\
\cline { 2 - 6 } & Slight & Moderate & Extensive & Complete \\
\hline \multirow{2}{*}{$\begin{array}{c}\text { Syiah } \\
\text { Kuala }\end{array}$} & $\mathrm{x}$ & 2.1 & 3.4 & 5.5 & 11.0 \\
\cline { 2 - 6 } & $\mathrm{y}$ & 1.3 & 2.2 & 3.4 & 6.0 \\
\hline \multirow{2}{*}{ Kutaraja } & $\mathrm{x}$ & 2.0 & 3.4 & 5.7 & 9.5 \\
\cline { 2 - 6 } & $\mathrm{y}$ & 0.5 & 1.3 & 1.7 & 3.1 \\
\hline \multirow{2}{*}{ Meuraxa } & $\mathrm{x}$ & 1.0 & 1.6 & 3.0 & 4.5 \\
\cline { 2 - 6 } & $\mathrm{y}$ & 0.4 & 0.7 & 1.0 & 2.2 \\
\hline
\end{tabular}

Table 9. The result of tsunami fragility curve

\begin{tabular}{|c|c|c|c|c|c|}
\hline \multirow{2}{*}{$\begin{array}{c}\text { Building } \\
\text { School }\end{array}$} & \multicolumn{4}{|c|}{ Inundation Depth (m) } \\
\cline { 2 - 6 } & Slight & Moderate & Extensive & Complete \\
\hline \multirow{2}{*}{$\begin{array}{c}\text { Syiah } \\
\text { Kuala }\end{array}$} & $\mathrm{x}$ & 4.5 & 6.0 & 8.3 & 15.0 \\
\cline { 2 - 6 } & $\mathrm{y}$ & 3.0 & 4.2 & 5.6 & 7.3 \\
\hline \multirow{2}{*}{ Kutaraja } & $\mathrm{x}$ & 3.6 & 5.2 & 6.5 & 8.5 \\
\cline { 2 - 6 } & $\mathrm{y}$ & 2.2 & 3.1 & 3.9 & 5.4 \\
\hline \multirow{2}{*}{ Meuraxa } & $\mathrm{x}$ & 3.5 & 5.0 & 6.4 & 8.2 \\
\cline { 2 - 6 } & $\mathrm{y}$ & 2.2 & 3.2 & 4.0 & 6.2 \\
\hline
\end{tabular}

In addition to earthquake and tsunami hazards, liquefaction vulnerability also needs to be taken care of on disaster mitigation. Based on the liquefaction potential map, school buildings in coastal sub-districts have vulnerabilities, which can be seen in Table 10 .

Table 10. Potential of liquefaction

\begin{tabular}{|c|c|}
\hline Building School & Potential Liquefaction \\
\hline Syiah Kuala & Light - Medium vulnerability \\
\hline Kutaraja & Light vulnerability \\
\hline Meuraxa & Light - Medium vulnerability \\
\hline
\end{tabular}

The results of the probabilistic analysis of damage based on the fragility curve can be used to predict the level of damage to buildings in the coastal district of Banda Aceh. For probabilistic earthquake susceptibility, the PGA earthquake magnitude is the main parameter that must be considered. In contrast, tsunami susceptibility can be seen based on the height of inundation that occurs in buildings. As well as earthquake and tsunami vulnerability, the liquefaction potential must also be 
considered because liquefaction also affects ground movement activity. The summary results of this study indicate that it is necessary to carry out periodic maintenance of school buildings in the coastal area of Banda Aceh city so that they become strong buildings and are ready to be used if a large-scale disaster occurs.

Acknowledgment. This research was conducted and performed under AAUI-MAIPARK Research Grant 2020 and funded by PT Reasuransi Maipark Indonesia. The authors are highly thankful to Dwi Agam Riantara and Farah Fadillah for their help in the data collection.

\section{References}

1. Bappenas and International Community, Indonesia: Preliminary Damage and Loss Assessment; The December 26, 2004, Natural Disaster, (Bappenas, Indonesia, 2006)

2. B. S. Nasional, Standar Nasional Indonesia 17262019: Tata Cara Perencanaan Ketahanan Gempa untuk Struktur Bangunan Gedung dan Non Gedung (BSN, Jakarta, 2019)

3. B. S. Nasional, Standar Nasional Indonesia 17272020: Beban Desain Minimum dan Kriteria Terkait untuk Perancangan Bangunan Gedung dan Struktur Lain (BSN, Jakarta, 2020)

4. R. Gentile, et al., From Rapid Visual Survey to Multi-Hazard Risk Prioritisation and Numerical Fragility of School Buildings, NHESS, 19: 13651386 (2019)

5. D. Vamvatsikos, and C. A. Cornell, Incremental Dynamic Analysis, EESD, 27(3): 97 - 125 (2002)

6. S. Karafagka, S. Fotopoulou, and K. Pitilakis, Analytical Tsunami Fragility Curves for Seaport RC Buildings and Steel Light-Frame Warehouses, SDEE, 112: 118-137 (2018)

7. Pusat Studi Gempa Nasional, Peta Sumber dan
Bahaya Gempa Indonesia Tahun 2017 (Kementerian PUPR, Bandung, 2017)

8. Badan Meteorologi Klimatologi dan Geofisika (BMKG) Data Base, Accesed on 25 April 2021.

9. E. Kalkan, dan A. K. Chopra, Practical Guidelines to Select and Scale Earthquake Records for Nonlinear Response History Analysis of Structures (Earthquake Engineering Research Institute, London, 2010)

10. H. Iemura, et al., Information Dissemination for Reality-Based Tsunami Disaster Education, Presented on The 14th World Conference on Earthquake Engineering (Beijing, China, 12-17 October 2008)

11. Tursina, and Syamsidik, Reconstruction of the 2004 Tsunami Inundation Map in Banda Aceh Through Numerical Model and Its Validation with PostTsunami Survey Data, IOP Conf. Series: Earth and Environmental Science, 273 (2019)

12. V. Tiwari, and A. Kasnale, Incremental Dynamic Analysis of RC Frames, IRJET, 4(6): 697-700 (2017)

13. K. Pitilakis, et al., SYNER-G : Typology Definition and Fragility Functions for Physical Elements at Seismic Risk, (Springer, Netherlands, 2005)

14. H. Sadraddin, Fragility Assessment of High-Rise Reinforced Concrete Buildings, (Civil and Construction Engineering Western Michigan University, Kalamazoo, 2015)

15. S. Medina, et al., Tsunami Analytical Fragility Curves for The Colombian Pacific Coast: A Reinforced Concrete Building Example, ES, 196 (2019) 109309.

16. FEMA, Direct Physical Damage-General Building Stock, (HAZUS-MH Technical manual, Chapter 5, Washington D.C., 2004)

17. I, Rusydy, et al., Shallow Crustal Earthquake Models, Damage, and Loss Predictions in Banda Aceh, Indonesia, GD, 7: 8 (2020) 